\title{
IMPACT OF THE NORM ON THE EXPLOITATION CHARACTERISTICS OF AGRICULTURAL MECHANIZATION IN THE REPUBLIC OF MACEDONIA
}

\author{
Zivko Davcev \\ Faculty of Agricultural Sciences and Food, \\ "Ss. Cyril and Methodius" University of Skopje. Republic of Macedonia \\ e-mail: davcevz@gmail.com
}

\begin{abstract}
The paper describes the results obtained from the questionnaires of four groups of tractor drivers by age structure related to the relationship during the exploitation of tractors and agricultural machinery. However, remarks and their opinions were taken with recommendations which should and how to change in the modern way in the exploitation of agricultural mechanization. With a special aspect of handling, maintenance, seen from the expertise and age structure of the tractor drivers themselves. An important segment occupies the set norm and the personal income of the tractor drivers themselves. It is a trend in introducing a new technique in agriculture, with modern, more productive. Which requires changing the norms, but it also requires changing the monthly income of the tractor drivers themselves. This is a very interesting factor that directly affects the storage and maintenance of agricultural machinery. It also depends on the appearance of defects as well as the total costs of servicing and repairs. That is why we took up the analysis of this issue, because one thing is related to each other and at the end of the year an analysis is made of the total costs that always appear in the exploitation as planned and unplanned and always arise as a result of less or greater concern of the immediate handlers. The problem is very interesting and from the aspect of education, which category of tractor drivers with different education is easier to handle, what kind of receipts are received and the attitude of the man to the machine. It is also interesting and contemporary issues, because in practice we are introducing more modern machines with abundant electronics and computerization that have already received very good trainings. Basically, if production technology changes due to modern agricultural machinery, then there is a necessity in changing the set norms and personal income.
\end{abstract}

Key words: agricultural machinery, exploitation.

\section{INTRODUCTION}

The tendency of introducing new agricultural mechanization in agricultural production is unstoppable, which is quite normal, since it also introduces new production technology for certain agricultural crops. Such is the tendency of agricultural production and modern machines are required which will be highly productive in order to perform a certain working process in a timely manner, qualitatively and economically.

In such a tendency, the important factor of the machines we enter is because the factories constantly improve their construction, constantly giving new models with modern devices and mechanisms, and most often with the possibility of applying integral technique and with precision during work. But there is an important segment where little attention is paid, and that is the attitude of the man with the machine. His ability and education and capacity to study contemporary constructions and all their opportunities and benefits to use to make it easier to achieve the set goal it's a quality and economical job.

The number of interested young professionals who want to dedicate themselves to work in this area decreases, find their basic existence, gain expertise in handling and maintenance, or respond to the demands of modern agricultural mechanization. There are many reasons for reducing the number of young professionals, and the main reason is the state of

IRTIIE Vol. 6, No. 2, 2018 ISSN 1314-8788 (print), ISSN 1314-8796 (online), doi: 10.15547/artte.2018.02.002 


\section{ARTTIE $Y$}

Ipplied Resseirlohes in Technics, Technologies and Bductation

Journal of the Faculty of Technics and Technologies, Trakia University https://sites.google.com/a/trakia-uni.bg/artte/

agriculture and agrarian policy that does not offer good working conditions, ie it offers small personal incomes during the month and inadequate working conditions. The problem also arises from the fact that now all major companies are private, and there is some opinion that tractors are not so important in the whole concept, little attention is paid to education, studying general knowledge of English. Little attention is paid to maintenance during exploitation, and whenever new machines are brought in, the norm increases because they are highly productive and according to the habit, the personal income remains alive or slightly corrected.

\section{PURPOSE OF THE TEST}

The immediate problem of the investigations and analyzes was the problem that appeared on the man - machine relationship. How the title was changed in agriculture, the agricultural holdings were privatized, new drives and attachments were introduced, and the ratio of personal income with the set norm was disturbed, such an interaction led to little concern in the management, maintenance, servicing and repair of agricultural machinery that had been seized to establish a new ratio. This phenomenon in some agricultural holdings has been omitted, not well realized and studied, and already if we introduce new machines and technology, such machines should be put in new relationships.

\section{FACILITY AND AREA OF EXAMINATION}

In order to realize the set goal, the surveys and surveys were made in three agricultural holdings, which have a total area of around 25000 ha with different agricultural crops, the surveyed tractors worked on different tractors in new and old models, under working conditions without changing the norm, the conditions at work and in certain ratios.

Methodology of work

We have set up a methodology of work by which the examinations and surveys that we were doing wanted to achieve the specific goal. In the methodology of work we covered three privately owned agricultural holdings that have different agricultural areas, crops, different types and categories of tractors and different ratios in the organization in terms of norm and personal income. In the questionnaires we gave, we divided two questionnaires into one questionnaire in response to questions 8 (eight), with short answers, giving a clear picture of the structure of tractors employed in the economy. Their expertise and their opinion on a certain issue, in order to get an even clearer picture, the questionnaire was divided into four categories of tractor drivers by age structure:

- First category age 25-35 years.

- Second category with age 35-45 years.

- Third category with age 45-55.

- Fourth category of tractors with over 55 years.

During the survey and examination, half of them wanted to write the name and surname and half did not want them. So, in the methodology of work, we did not insist on writing a name, a real answer to the questions asked.

However, in the course of the examination and the questionnaire, we set up another 6 (six) questionnaires and grouped them in the sense of giving their own opinions and recommendations for which they consider and want to say, in order to actually pay off personal income, to finds a ratio of personal income and the set norm. Something to suggest that will be in the interest of the work as well as the care and the ratio of the machines they are handling.

In the examined parameters as well as in the survey observations, 8 (eight) tractor drivers from each generation were examined and they responded to the questions asked, which we

IRTIIE Vol. 6, No. 2, 2018 ISSN 1314-8788 (print), ISSN 1314-8796 (online), doi: 10.15547/artte.2018.02.002 


\section{ARTITIE}

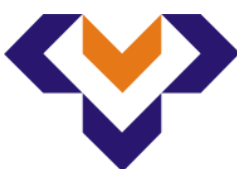

Ipplied Resseirl'hes in Teednicis, Technologies and Eductation

Journal of the Faculty of Technics and Technologies, Trakia University https://sites.google.com/a/trakia-uni.bg/artte/

tabulated defiantly with either yes or no, or ambiguously. We filled in the tables and notes during the working process directly on the field and most often during the breaks, which were very short in time at most $10 \mathrm{~min}$ or during lunch, which lasted about $20 \mathrm{~min}$. It was the most convenient time since after the working day they were tired, they were in a hurry, and during the work we did not have much time because the criteria for working in the three economies were similar because everywhere was working on the set norm to get a certain daily allowance.

Analysis of the results obtained and survey surveys

The results obtained from the trials and surveys are shown in Table 1 and 2. The results presented by generators of tractor tractors show the actual situation and are presented as average values from the assessments. If the data presented in Table 1 and 2 are seen, that there is a big difference in the responses between tractors with different age structure but also different responses of tractors in the same age structure.

Table 1. Examined parameters for four generations of tractor drivers

\begin{tabular}{|c|c|c|c|c|c|c|}
\hline \multicolumn{3}{|c|}{ Anchor issues } & $\begin{array}{l}25-35 \\
\text { years }\end{array}$ & $\begin{array}{l}35-45 \\
\text { years }\end{array}$ & $\begin{array}{l}45-55 \\
\text { years }\end{array}$ & $\begin{array}{l}<55 \\
\text { years }\end{array}$ \\
\hline \multirow{3}{*}{1.} & \multirow{3}{*}{ Knowledge of English } & - $\quad$ Active & 1 & 1 & - & - \\
\hline & & - $\quad$ Passively & 4 & 3 & 2 & - \\
\hline & & - $\quad$ Beginner & 3 & 4 & 2 & - \\
\hline \multirow{2}{*}{2.} & \multirow{2}{*}{ Trainings in the country } & - Yes & 6 & 6 & 7 & 7 \\
\hline & & - No & 2 & 2 & 1 & 1 \\
\hline \multirow{2}{*}{3.} & \multirow{2}{*}{ International Trainings } & - Yes & 1 & 2 & 3 & 4 \\
\hline & & - No & 7 & 6 & 5 & 4 \\
\hline \multirow{3}{*}{4.} & \multirow{3}{*}{$\begin{array}{l}\text { Are you satisfied with the } \\
\text { financial moment? }\end{array}$} & - Yes & 3 & 5 & 2 & 1 \\
\hline & & - $\quad$ No & 3 & 2 & 5 & 5 \\
\hline & & - $\quad$ Yes/ No & 2 & 1 & 1 & 2 \\
\hline \multirow{3}{*}{5.} & \multirow{3}{*}{$\begin{array}{l}\text { Are the established norms for } \\
\text { work processes real? }\end{array}$} & - Yes & 3 & 2 & 1 & - \\
\hline & & - No & 3 & 3 & 5 & 6 \\
\hline & & - $\quad$ Yes/No & 2 & 3 & 2 & 2 \\
\hline \multirow{3}{*}{6.} & \multirow{3}{*}{$\begin{array}{l}\text { monetary compensation / } \\
\text { production norm }\end{array}$} & - Good & 4 & 3 & 2 & 1 \\
\hline & & - No good & 2 & 2 & 3 & 4 \\
\hline & & - Good/ No good & 2 & 3 & 3 & 3 \\
\hline \multirow{3}{*}{7.} & \multirow{3}{*}{$\begin{array}{l}\text { Are you satisfied with the } \\
\text { working conditions? }\end{array}$} & - Yes & 2 & 4 & 3 & 2 \\
\hline & & - $\quad$ No & 2 & 1 & 2 & 1 \\
\hline & & - $\quad$ Yes/No & 4 & 3 & 3 & 5 \\
\hline \multirow{3}{*}{8.} & \multirow{3}{*}{ Human-machine relationship } & - Good & 2 & 2 & 2 & 1 \\
\hline & & - No good & 2 & 2 & 4 & 3 \\
\hline & & - $\quad$ Yes/No & 4 & 4 & 2 & 4 \\
\hline
\end{tabular}

Certainly, the basic question and the first question in the survey was knowledge of English and other parameters from the educational programs. It is quite normal because new drives and connecting machines are constructively ample with modern devices and mechanisms that are prescribed in the manuals and most often in English. Theoretical knowledge of them should be applied and maintained. Since three age structures of tractor drivers were taken, and from the table itself, it is noticed that none of them attend English language courses. The general knowledge they possess is owed as a result of staying abroad on various grounds or studying English in primary and secondary education. How they understand the catalogs and the manuals was one of the questions, and the answer was that if they needed someone else who knew English, and most often an interpreter, they used it.

IRIIIE Vol. 6, No. 2, 2018 ISSN 1314-8788 (print), ISSN 1314-8796 (online), doi: 10.15547/artte.2018.02.002 


\section{AR'TIE \\ ( \\ Ipplied Ressearlohes in Technics, Technologies and Bductation \\ Journal of the Faculty of Technics and Technologies, Trakia University https://sites.google.com/a/trakia-uni.bg/artte/}

Have they done training in the country and abroad the answer was that everyone has training, with a special note that in the previous period the trainings were frequent both in the country and abroad and more attention was paid to the educational process for certain lines machines. However, it was particularly significant as an impression of four generations of tractor drivers. They say they are positive about the training in the country and they express a wish for more frequent trainings. It is a general impression that the trainings made are insufficient because new machines with perfect devices and mechanisms are introduced every two years.

A very important impression left the training abroad. From the analysis, we noticed that, as well as from the statistical data, $97 \%$ of the mechanization used by our farmers is imported. All drives are imported from the eastern and western countries; all with different designs and features, but for both manufacturers and general dealers offer free trainings for all. From the results obtained in item 3 in Table 1, it is notable that a small number of the last decade was on such trainings, under the same exact number. 3 their number with trainings abroad is increasing, but it was in another time and another period.

Significant attention was devoted to obtaining results in item no.4. The question was simple. Are you satisfied with personal income?

The answers to us were not expected because the younger generations expressed satisfaction with personal income, they informed us with a contractual understanding that their personal income ranges from 500-600 Euros, discrete data, not publicly, with a plea not to write a name and surname because they were relations in the agricultural economy, worked on new modern machines with a defined norm. Older generations had a case where their personal income of $60-90 \%$ was lower than the personal income of the younger generations. Some of them worked on newer ones on older machines. In the same working conditions, the number of hours worked on Sunday expressed open dissatisfaction. Of particular interest was the question of whether the established norm for certain works processes is realistic whether it can be fulfilled in order to receive the expected personal income. From the table itself in point 5 it is notable that younger generations with better machines, highly productive, in favorable working conditions and with fewer defects, were satisfied with the set norm. Older generations of tractor drivers were unhappy, it was noteworthy from the analysis done that before 20 years they worked on the same fields but with a lower rate than now. Although nowadays they have more advanced mechanization, the reason is that the older tractors work on older tractors with smaller maneuvering possibilities, more frequent defects and difficulty meeting the norm.

In order to complete this topic, the issue with the questionnaire was asked about the ratio of the personal income with the norm. Much was discussed and analyzes of this question were made. The younger generations expressed their satisfaction and said that the norm could realistically be achieved and the personal income realized. Older generations did not express satisfaction because they had less personal income and less the norm to take that personal income. The reason was reflected in the fact that the plots do not have the same dimensions of some of them have different obstacles, the working conditions were almost the same and the working hours during the day ran from 10-11h. Sometimes, some days and 12 working hours. It was generally unheeded by the fact that that personal income corresponds to 8 hours of working time, and for the extra working hours they demanded a coefficient that would be twice the amount that the regular working hour is paid. From the analysis of the coefficient paid for overtime, it turned out that it is not the same for all tractors, ie the younger generation is larger and the older is smaller. What is the decision of the manager himself? Analyzing this, there was also a mutual revolt among tractor drivers, because in different age structure of tractors, the left norm differed, which basically led to the difference in personal income. 
Table 2. Annotative notes with opinions and recommendations of tractor drivers taking into account age structure

\begin{tabular}{|c|c|c|c|c|c|c|}
\hline \multicolumn{3}{|c|}{ Inquiry notes } & $\begin{array}{l}25-35 \\
\text { years }\end{array}$ & $\begin{array}{l}35-45 \\
\text { years }\end{array}$ & $\begin{array}{l}45-55 \\
\text { years }\end{array}$ & $\begin{array}{l}<55 \\
\text { years }\end{array}$ \\
\hline \multirow{2}{*}{1.} & \multirow{2}{*}{ Do you need more training? } & Yes & 8 & 7 & 8 & 7 \\
\hline & & No & 0 & 1 & 0 & 2 \\
\hline \multirow{2}{*}{2.} & \multirow{2}{*}{$\begin{array}{l}\text { Is overtime payable Saturday, Sunday } \\
\text { and holiday? }\end{array}$} & Yes & 8 & 8 & 8 & 8 \\
\hline & & No & 0 & 0 & 0 & 0 \\
\hline \multirow{3}{*}{3.} & \multirow{3}{*}{ Is service and repair satisfactory? } & Yes & 2 & 2 & 3 & 2 \\
\hline & & No & 2 & 2 & 3 & 2 \\
\hline & & Yes/ No & 4 & 4 & 2 & 4 \\
\hline \multirow{3}{*}{4.} & \multirow{3}{*}{ Condition with the supply of spare parts } & Yes & 2 & 2 & 3 & 2 \\
\hline & & No & 2 & 2 & 3 & 3 \\
\hline & & Yes/ No & 4 & 4 & 2 & 3 \\
\hline \multirow{3}{*}{5.} & \multirow{3}{*}{ Whether to work in two shifts? } & Yes & 4 & 4 & 6 & 6 \\
\hline & & No & 2 & 3 & - & 1 \\
\hline & & Yes/ No & 2 & 1 & 2 & 1 \\
\hline \multirow{3}{*}{6.} & \multirow{3}{*}{$\begin{array}{l}\text { Will increase productivity and care for } \\
\text { agricultural machines as you get more } \\
\text { money? }\end{array}$} & Yes & 6 & 7 & 8 & 8 \\
\hline & & No & - & - & - & - \\
\hline & & Yes/ No & 2 & 1 & - & - \\
\hline
\end{tabular}

It is undoubtedly that the results obtained in item 1 of Table 2 show that the introduction of new mechanization requires increased training. They themselves point out that their work will be easier and there will be fewer defects and slowdowns. The current mode of training is unsatisfactory especially for a group of precise machines such as redundant workers, and the training is done with one another on the spot by showing what is good, but it is not a regular occurrence.

In table 2. It was a very interesting question that was answered without dilemma and referred to the ratio of the norm and the payment for overtime and work during days of weekend or holidays. The suggestion was that for those working hours the payment should be twice the ratio than the regular working hour, ie a weekly work of 42 working hours. It was noticeable that the eight working hours were regularly paid off and optimally, and overtime did not sufficiently lead to a situation of caring for the machine, the tractor driver's commitment to proper handling and maintenance during work was reduced. Therefore, in item 2, all tractor drivers surveyed by generational age were unanimous that the nerve set is not a problem, but a problem is the coefficient of payment.

The third question from the table number 2. Was service, repair. Whether the service workshops are well surveyed with professional personnel and equipment for servicing modern mechanization, and here the dominant ambiguous answers are indications that it is not enough either for staff or equipment and is generally noticeable that the Republic of Macedonia's trend of procurement for servicing and overhauling is lagging behind. We did not build a type of repair centers with educated staff for repairing and servicing modern devices and mechanisms in the machines, but this point points to and we connected with item 4 that such insufficient staffing leads to a halt in work and this is precisely the interesting question where not the regular addition of parts and repair the machine for a longer period is out of use. The traitor is unable to work and achieve a certain daily income by fulfilling the norm and overcoming it. In those days, the tractor driver either goes on a replacement or does another job, but then he receives a much lower director's daily allowance, which is usually around 10 Euros.

In Table 2. In item number 5, the problem of working in two shifts was analyzed. This exploitation issue is related to transport from the place of residence to the plot and other IRTIIE Vol. 6, No. 2, 2018 ISSN 1314-8788 (print), ISSN 1314-8796 (online), doi: 10.15547/artte.2018.02.002 


\section{ARTTIE $Y$}

Ipplied Resseirlohes in Technics, Technologies and Bductation

Journal of the Faculty of Technics and Technologies, Trakia University https://sites.google.com/a/trakia-uni.bg/artte/

organizational issues. However, this issue is quite justified in terms of exploitation of working hours, whose coefficient will undoubtedly increase to 0.8 . Then the worker will not get tired, he will perform the work process quality and will have enough concentration to pay attention to the work of all machine parts so that no unpredictable defect occurs that we analyzed in the points in table number 1 and are associated with random or non-accidental defects as a result of fatigue and negligence at work for more than 10 hours during the working day. The table itself dominates the responses for working in two shifts, but with mentioning the organizational activities to be arranged, and the personal income corresponds with the time and the norm.

However, it remains interesting to ask whether personal income should be linked to the norm or vice versa with which the work will go normally and quality will be performed. With greater attention in handling agricultural machinery, but the plan to be a ha-surface designed for individual work processes of individual crops.

To reveal the problem in the analysis, the reasons and attitudes and what they want to say as tractor drivers and can not or have fear. Another question number 6 was raised. Very interesting answers were received and the basis of the answer was that they were not satisfied with the ratio of the norm and the personal income although they never mentioned that they did not care enough for proper handling and maintenance during the exploitation. However, it is pointed out in point 6 that a conclusion can be drawn that if the set norm is well paid and overtime is paid, it will have increased concern for machines with fewer defects.

During the surveys and analyzes, we did not get into that part precisely because of this last question. How much does the delay, the service and the repair of agricultural machinery cost, due to not enough care expressed in the amount of Euros.

\section{CONCLUSIONS}

1. The introduction of new mechanization implies the necessity of continuous education, which is a basic requirement for proper exploitation with fewer defects and more costeffective work.

2. The biggest defects arise from a small commitment in the course of work, and are due to a poorly established norm, inadequate personal income and a small overtime payment.

3 . With the introduction of new mechanization, it is necessary to change the attitude of the machine, to improve working conditions, protection at work, etc.,

4. All stated leads to the necessity of creating new relations of managers in the agricultural economy with tractors, because the market economy has a share and influence in the application of the new mechanization

\section{LITERATURE}

[1] Tassev G. Basics of technical diagnostics of machines, Sofia, Avangard Prima, 2010.

[2] Tassev G. Mechanization of agricultural production, Sofia, Avangard Prima, 2010.

[3] Tassev G., Madzhov S., Ivanova N. Management of technogenic risk, Sofia, Avangard Prima, 2017.

[4] Davcev Z. Exploatation of agricultural machinery, Scopje, Faculty of Agricultural Sciences and Food, 2007.

[5] Tasev G., Ivanova N., Georgieva K. Structure of quality and dipendability of machinen, IV International scientific congress, Varna 2016, Bulgaria.

[6] Mihov M. Research and development of a probabilistic method to determine the number of spare parts IV International scientific congress, Varna 2016, Bulgaria. 